\title{
Physicochemical quality of early-maturing 'Navel' sweet oranges
}

\section{Qualidade físico-química de laranjas 'Bahia’ de maturação precoce}

\author{
Fernando Alves de Azevedo ${ }^{1 *}$; Evandro Henrique Schinor ${ }^{2}$; \\ Patrícia Marluci da Conceição²; Camilla de Andrade Pacheco ${ }^{3}$; \\ José Dagoberto De Negri ${ }^{1}$; Mariângela Cristofani-Yaly ${ }^{1}$
}

\begin{abstract}
The cultivation of new types of oranges can be a good alternative for citrus growers because there is a growing domestic market and good export prospects. Due to these expectations, it is essential to search for new cultivars for use in the fresh fruit industry. Therefore, the aim of this work was to physicochemically characterize the fruits of new cultivars of 'Navel' oranges, seeking alternatives with good characteristics, such as earliness, lack of seeds, good color and organoleptic characteristics desired by the consumer market. The fruits of five new cultivars of 'Navel' orange were evaluated, namely, 'Bahia Valente' (CN 28), 'Golden Nugget Navel' (CN 41), "Robertson Navel” (CN 39), 'Washington Navel' (CV 27) and 'Washington Navel I' (CN 34), during two harvest seasons (2012/2013 and 2013/2014). The following physicochemical variables were quantified: mass, peel color, juice yield, acidity, soluble solids and ratio. The cultivars studied were compared to the commercial cultivar 'Bahia Cabula' (CV 25). The new cultivars produced fruit with standards that met consumer expectations, with fruit mass suitable for sale of the fresh fruit, good yield juice and early maturation (March), which enables harvesting 'Bahia Cabula' in the off-season period. Thus, it is concluded that there are navel orange cultivars with acceptable physicochemical qualities and early maturation.
\end{abstract}

Key words: Citrus sinensis. Off-season. Fresh fruit. Orange navel.

Resumo

O plantio de novos tipos de laranjas pode ser boa alternativa aos citricultores, pois há um mercado interno crescente e boas perspectivas de exportação. Em decorrência dessas expectativas torna-se primordial buscar novas variedades para o segmento de frutas frescas. Portanto, objetivou-se, com este trabalho, caracterizar físico-quimicamente frutos de novas variedades de laranjas tipo 'Bahia', buscando opções que apresentem boas características, como precocidade de produção, ausência de sementes, boa coloração e características organolépticas aceitas pelo mercado. Dessa forma, foram avaliados frutos de cinco novas variedades de laranja doce, tipo 'Bahia': 'Bahia Valente' (CN 28), 'Golden Nugget Navel' (CN 41), 'Robertson Navel' (CN 39), 'Washington Navel' (CV 27) e 'Washington Navel I' (CN 34), durante duas safras (2012/2013 e 2013/2014), quantificando-se as seguintes variáveis físicoquímicas: massa, coloração da casca, rendimento de suco, acidez, sólidos solúveis e ratio. As variedades em estudo foram comparadas à variedade comercial 'Bahia Cabula' (CV 25). As novas variedades produziram frutos com padrões requeridos pelo mercado consumidor, com massa do fruto adequada para venda in natura, bom rendimento de suco e maturação precoce (março), que proporciona a colheita na entressafra da 'Bahia Cabula' no mercado. Dessa forma conclui-se que há variedades tipo Bahia, com qualidade físico-química aceitável e de ciclo precoce.

Palavras-chave: Citrus sinensis. Entressafra. Fruta de mesa. Laranja de umbigo.

\footnotetext{
${ }^{1}$ Pesquisadores, Centro de Citricultura Sylvio Moreira, Instituto Agronômico, IAC, Cordeirópólis, SP, Brasil. E-mail: fernando@ centrodecitricultura.br; dagoberto@centrodecitricultura.br; mariangela@centrodecitricultura.br

2 Profs., Centro de Ciências Agrárias, Universidade Federal de São Carlos, UFSCAR, Araras, SP, Brasil. E-mail: ehschinor@cca. ufscar.br; patricia@cca.ufscar.br

${ }^{3}$ Prof $^{\mathrm{a}}$, Departamento de Agronomia, Universidade Estadual de Londrina, UEL, Londrina, PR, Brasil. E-mail: camilla_andrade@ yahoo.com.br

* Author for correspondence
} 


\section{Introduction}

Orange trees are one of the most known, cultivated and studied fruit trees worldwide. They were introduced to Brazil by the Portuguese around 1540, probably in the state of Bahia (BA). On the outskirts of Salvador, the orange 'Navel', also called 'Bahia', was selected, probably from a mutation of the cultivar 'Seleta', before the 1800s. It then spread everywhere, reaching California in the United States, where it was later considered the most valuable introduction ever made by the United State Department of Agriculture in the way of fruits (PASSOS, 1998).

The diversified cultivation of 'Bahia' orange cultivars is a good option for citrus growers when produced using a technology-based system and, especially, outside the harvest peak (May/July), i.e., in the off-season period. This is due to the growing and highly valued domestic market in addition to good export prospects because it is a seedless fruit and widely accepted internationally, where it is known as 'Navel'.

In Brazil, the main cultivars of the Bahia group are the oranges 'Bahia Cabula' and 'Baianinha', which present the following main characteristics: large fruit, easy to peel, seedless and good quality of fresh fruit due to its good internal and external color, in addition to its pleasant flavor. However, the cultivars of this group are not used for industrial processing because, shortly after being processed, the juice develops a bitter taste due to the presence of limonin, which is characteristic of this group (ISIDORO et al., 2012). Another characteristic of navel oranges is that the cells of the pollen grains disintegrate, thus precluding their formation, and the embryo sac is usually sterile, leading to the production of seedless fruits even in the presence of other pollinating cultivars (OLIVEIRA et al., 2004).

There has been decreasing interest in the cultivation of cultivars of this type of orange, mainly due to the decrease in exports, which was quite significant in the past. In addition, prices in the domestic market have been lower than expected by the producers. In 2003 , only $0.28 \%$ of seedlings in São Paulo nurseries were 'Bahia Cabula' oranges (PIO et al., 2005). However, it is worth stressing that new market niches are emerging in Brazil, creating the need to overcome barriers to the competitive expansion of Brazilian fruit. This can occur through promotion of the consumption of fruit marketed in Brazil, emphasizing its nutritional power and human health benefits (PEREIRA et. al., 2006); the training of small producers by providing information, including novel crop management practices and technology, always seeking their alliance to ensure supply control and in the joint search for solutions for the industry (PIMENTEL; PIMENTEL, 2002); and the use of resistant cultivars that enable economic production without plant health problems (PACHECO et al., 2012; BASTIANEL et al., 2014).

However, to offer good quality fruit to the market, special care is needed in the harvest phase. The measurement of harvest indices, such as soluble solid content, peel color, and titratable acidity, among others, will help determine the maturation index and, consequently, define the optimal harvest time, which is essential to ensure good quality of the fruit for marketing and other processes. Thus, diversified cultivation of quality oranges produced using a technology-based system is a good option for citrus growers due to the growing domestic market and good export prospects (ROSSI; TORKOMIAN, 2015).

This work aimed to characterize the quality of the fruits of new cultivars of navel oranges, seeking options with good characteristics for the fresh fruit sector, such as earliness, lack of seeds, good peel color and the organoleptic characteristics desired by the consumer market.

\section{Materials and Methods}

Five navel orange cultivars were studied: 'Bahia Valente' (CN 28), 'Golden Nugget Navel' (CN 
41), 'Robertson Navel' (CN 39), 'Washington Navel' (CV 27) and 'Washington Navel I' (CN 34), grafted in a Rangpur lime tree (Citrus limonia Osbeck). All cultivars were introduced in Brazil by the Citriculture Center, Agronomic Institute (IAC) on May 20, 1941, and originated from the Citrus Experimental Station of Riverside, California, USA. They were then multiplied and stored in the Active Citrus Germplasm Bank of IAC, located in Cordeirópolis, state of São Paulo (SP), Brazil (Archives of the Citriculture Center).

The orchard it was planted using spacing 7 meter inter-rows and 4 meter between plants, in the municipality of Holambra, SP, in 1997. The experimental area is located in the Mideast region of São Paulo state, at latitude $22^{\circ} 37^{\prime} 36^{\prime \prime}$ south and longitude $47^{\circ} 03^{\prime} 36^{\prime \prime}$ west, with an average altitude of $600 \mathrm{~m}$ above sea level, an accumulated rainfall of 1,305 $\mathrm{mm}$ of rainwater, and Cwa climate, according to the Koppen classification. The experimental design was randomized blocks in a factorial arrangement of 4 (months of evaluation) x 6 (cultivars) x 2 (years), with 4 replicates and each plot consisting of 12 plants distributed in 3 rows. For comparison with the cultivars studied, the 'Bahia Cabula' (CV 25) cultivar was also cultivated; this is one of the navel orange cultivars widely used for commercial cultivation. The orchard was managed using routine crop management practices for navel oranges, with irrigation; proper and uniform management of pests, diseases, and weeds; and corrections of the soil $\mathrm{pH}$ and application of mineral fertilizers following the recommendations of Bulletin 100 (Boletim 100; IAC).

In 2013 and 2014, always between the tenth and twentieth day of the month, fruits from each cultivar were collected for physicochemical quality analysis. These samplings were conducted in 4 consecutive months: March, April, May and June, which comprise the maturation period of the cultivars studied, corresponding to 6, 7,8 and 9 months after anthesis. The 4 plots, which were composed of 12 plants each, were sampled, with ten fruits being collected from the 2 central plants, randomly around each plant, at 1.5 meters from the canopy.
The fruit samples were sent to the Laboratory of Fruit Quality Analysis of Citriculture Center (IAC). The fruit peel color was assessed in a Minolta CR 300 colorimeter by measuring the values of $L$ (lightness), $a$ (green to red range) and $b$ (blue to yellow range). The values $L, a$ and $b$ were then used to calculated the color index using the formula $\mathrm{CI}=$ $(1000 \times \mathrm{a}) /(\mathrm{b} \times \mathrm{L})$. This index varies approximately between -20 and +20 (Hunter color scale). Values between +7 and -7 correspond to yellow-green hues ( -7 to 0$)$, pale yellow to orangey-green hues (values close to zero) and pale orange to intense orange hues $(0$ to +7$)$; higher values correspond to more intense colors (JIMENEZ-CUESTA et al., 1983).

The total mass of the fruits of the sample was obtained using a Filizola scale, with onegram precision, and the individual fruit mass was subsequently calculated. The juice mass was obtained after crushing the fruit in an OIC extractor (OTTO 1800 model) to obtain the juice yield through the juice mass/fruit mass ratio, expressed as percentage.

The soluble solid (SS) content was determined by direct reading in a refractometer, and total titratable acidity (TA) was obtained by titration of $25 \mathrm{~mL}$ of juice to the point of neutralization with sodium hydroxide solution at 0.3125 normality, using phenolphthalein as an indicator. The ratio was obtained by the direct relationship SS/TA.

According to the Brazilian Program for Improvement of Commercial Standards and Packaging of Fruits and Vegetables of the Horticulture Quality Center (CEAGESP, 2000), the quality values considered ideal for the state of Sao Paulo and used as parameters in this work are juice yield between 35 and $45 \%$; soluble solid content of 9 to $10^{\circ}$ Brix; and ratio $\geq 9.0$.

The mean values obtained in each of the assessments were subjected to analysis of variance, and a regression analysis was conducted whenever there were significant differences. 


\section{Results and Discussion}

There was no effect of the year (2013 and 2014) on the fruit characteristics evaluated. The climate data for the two periods of evaluation show similar values of accumulated rainwater and average temperature (Figure 1). However, there was an interaction between the cultivars evaluated and the sampling periods (months after anthesis).

Figure 1. Rainfall and average temperature during the evaluation period of 'Navel' orange cultivars (Mogi Mirim, Sao Paulo State, Brazil, 2012-2014-30 km from the experimental area).

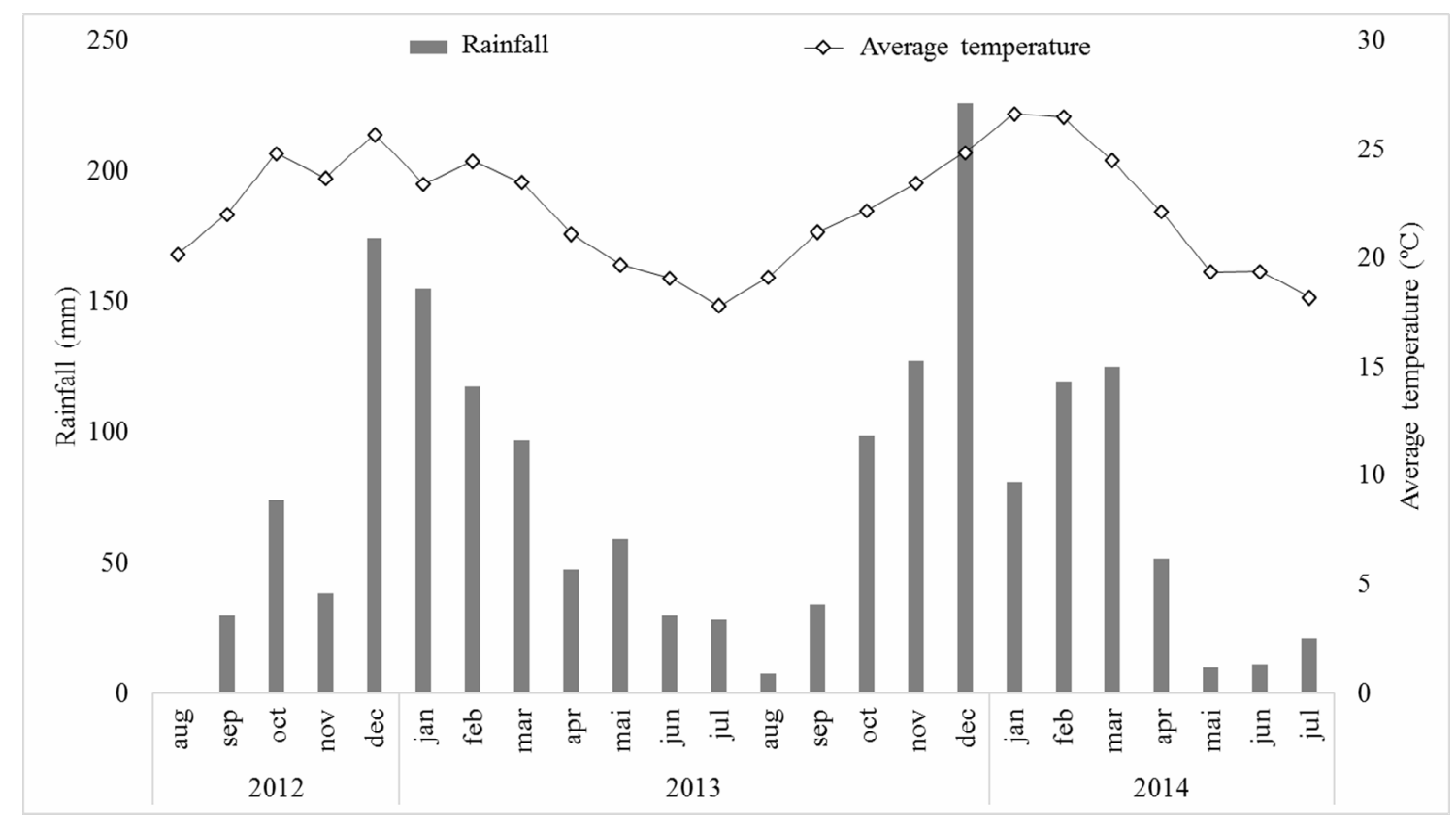

\section{Fruit peel color}

The color index values were larger for the group of new navel orange cultivars evaluated, indicating an earlier maturation than 'Bahia Cabula' (CV 25), which was used as the standard (Figure 2). Negative color index values indicate a greenish color; the more positive these values are, the more orange the fruit is. According to Gutierrez (2006) and Pacheco et al. (2014), there is a consumer preference for orange color fruit. The market rejects a greenish hue, except when the product is scarce (off-season). Thus, the only cultivar that presented unacceptable color (yellow-green) for marketing in the evaluated period was 'Bahia Cabula' - CV 25 (Figure 3). 
Figure 2. Color index of the fruit peel of 'Navel' orange cultivars sampled 6 to 9 months after anthesis (Holambra, SP, 2013-2014).

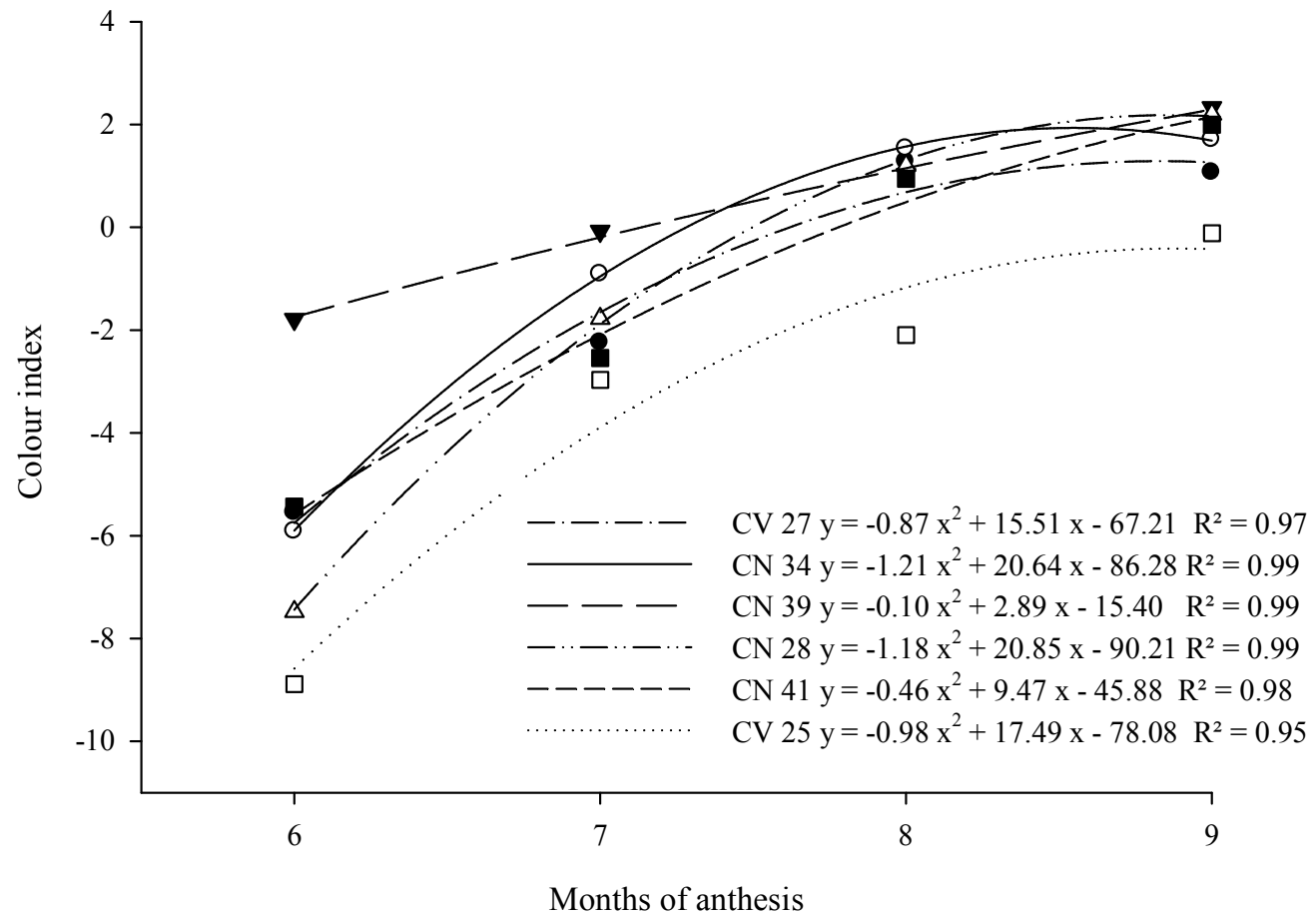

Figure 3. Fruits of the cultivars 'Bahia Cabula' CV 25 (A), 'Golden Nugget Navel' CN 41 (B), 'Bahia Valente' CN 28 (C), 'Washington Navel I' CN 34 (D), 'Washington Navel' CV 27 (E) and 'Robertson Navel' CN 39 (F) harvested in April, 7 months after anthesis (Holambra, 2013).
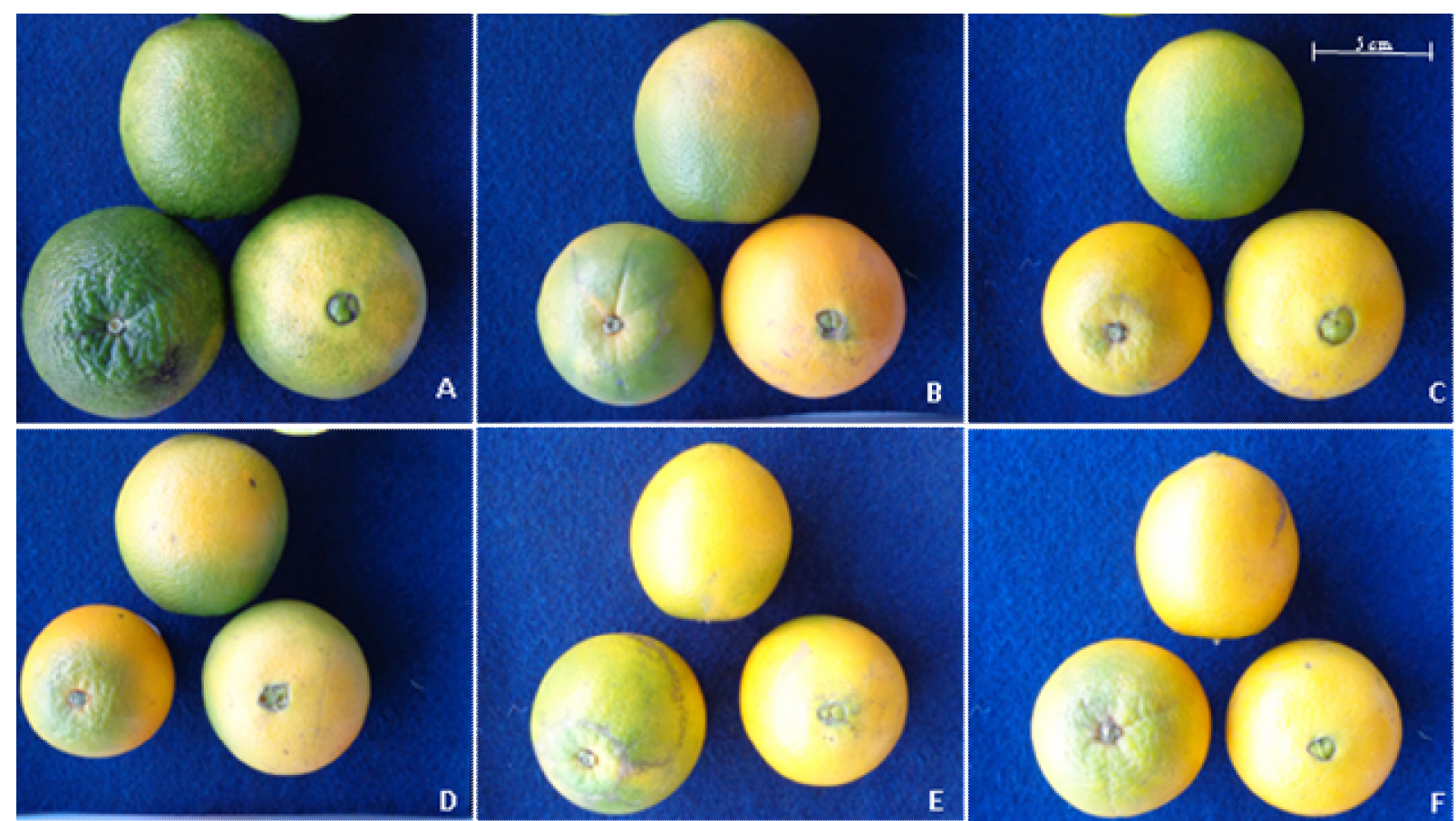
The change in the peel color of citrus fruit is related to the degradation of chlorophyll and exposure of carotenoids, which occur gradually over time. Following the increase in CI, there is an increase in chlorophyllase activity and a concomitant decrease in the chlorophyll content of the flavedo (JOMORI et al., 2014). According to Rodriguez (1987), Gayet and Salvo Filho (2003) and Nascimento and Santos (2013), at colder temperatures, the determination of the harvest time based on changes in peel color is masked by an accelerated decrease in chlorophyll content and an increase in carotenoid pigments in the fruit peel. In this work, peel color changes were accompanied by changes in the internal quality of the fruit (soluble solids, acidity and ratio).

\section{Fruit mass and juice yield}

All cultivars evaluated had fruits with smaller mass values at 6 and 7 months after anthesis (Figure 4 A) compared to the standard cultivar, 'Bahia Cabula' (CV 25), but that were suitable for the fresh fruit market as specified by the CEAGESP (2000). No cultivar presented fruits with mass below 150 $\mathrm{g}$, showing their potential for use in the fresh fruit market (CAPUTO et al., 2012).

Figure 4. Fruit weight (A) and juice yield (B) of the orange cultivars 'Washington Navel' (CV 27), 'Washington Navel I' (CN 34), 'Robertson Navel' (CN 39), 'Bahia Valente' (CN 28), 'Golden Nugget Navel' (CN 41) and 'Bahia Cabula' (CV 25) 6 to 9 months after anthesis (Holambra, SP, 2013-2014).
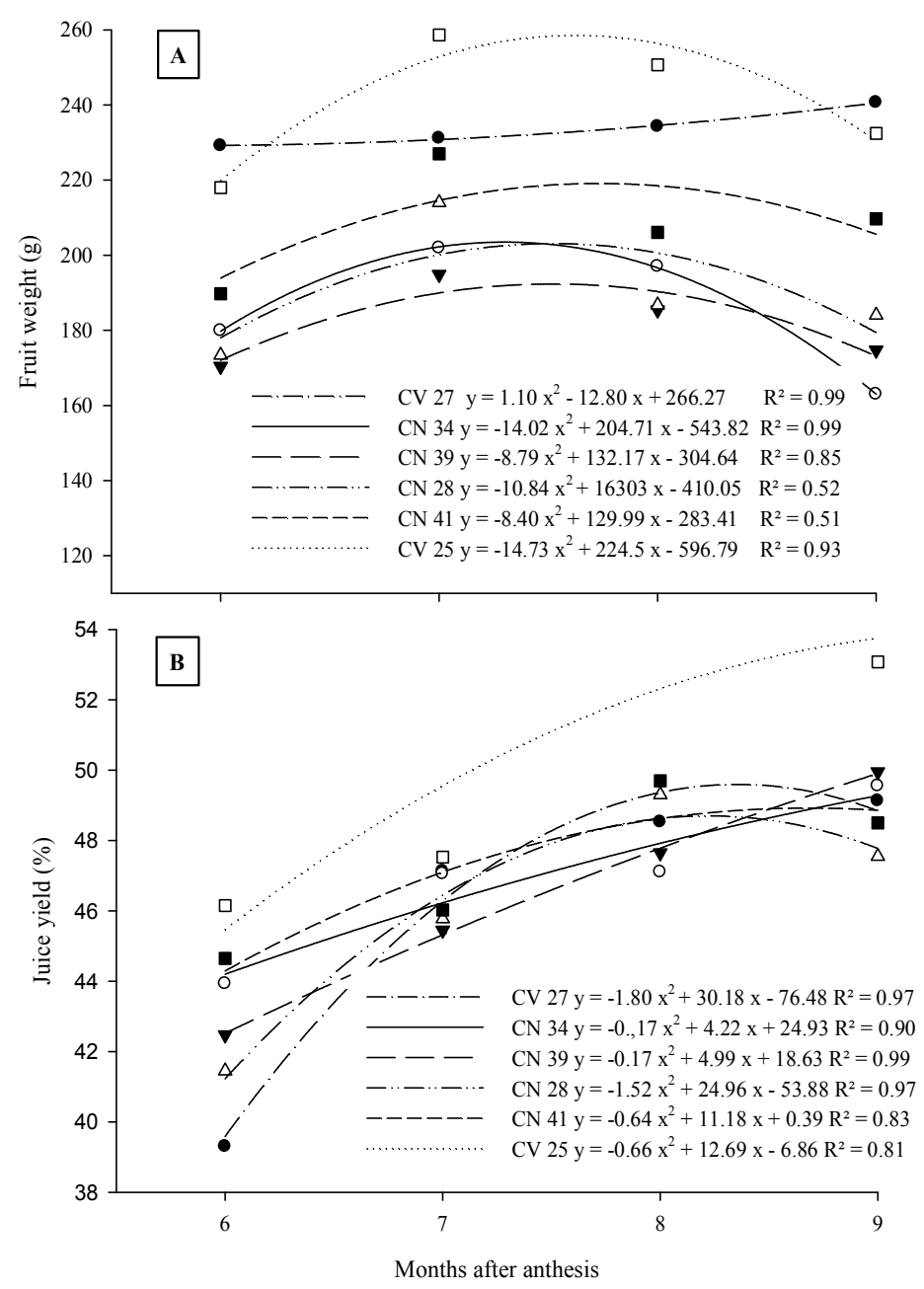
Despite the lower mass, at 6 and 7 months after anthesis - March and April (Figure 4 A) the cultivars studied presented mass gains similar to that of the standard cultivar. In most cultivars, there is a decreasing trend of mass values in the month of June (9 months after anthesis), which is directly related to low water availability in this period (Figure 1). The fruits usually lose mass in the winter months and, with the return of water with the spring rains, there is a fast and continuous mass gain (ALBRIGO, 1992; MACHADO et al., 2002). This occurs mainly in late cultivars, such as 'Valencia' and 'Natal' orange, but is also observed in early and mid-season cultivars.

The juice yield was higher than $35 \%$ in all seasons (Figure $4 \mathrm{~B}$ ); this value is considered suitable for marketing of orange fruit in the state of São Paulo (GRIZOTTO et al., 2012; BRUGNARA et al., 2009; CEAGESP, 2000). The high percentage of juice is a very interesting characteristic for citrus cultivars, both for those that will be used for fresh consumption and those used for processing (BARBASSO et al., 2005).

The value paid for navel oranges in trade centers takes into account the number of dozens per box, classifying the fruits according to their mass and diameter and placing then into three categories (A, $\mathrm{B}$ and $\mathrm{C}$ ), with category A being the most valued (GUTIERREZ, 2006). This fact highlights the need for fruit with good diameter to obtain better market prices. The fruits of the cultivars evaluated would fit into category B and would have a good value (data not shown).

\section{Soluble solid content and acidity of the juice}

The soluble solid content of the juice of all cultivars increased over the evaluation months, indicating an increase in sugar content, which was higher in the new cultivars than in 'Bahia Cabula' (CV 25), thus indicating earlier maturation of the former (Figure 5A).
Studies conducted by Ziegler and Wolfe (1975) consider that the minimum soluble solid (SS) content for the fruit to be considered ripe is $9{ }^{\circ} \mathrm{Brix}$. The soluble solid content in the fruit juice of all cultivars studied was greater than that reference value in the months evaluated. For citrus cultivars, the relationship between soluble solid content and acidity (ratio) is one of the most important characteristics because it helps determine the maturation point of the fruit. Tests conducted by Chitarra and Chitarra (1990) using sensory analysis demonstrated that oranges with a ratio above 9.510:1 (soluble solids:acidity) are appreciated by consumers, thus confirming the importance of high sugar levels in fruit.

The acidity levels decreased gradually over the evaluation months (Figure 5 B). The levels obtained were consistent with the maturation of the fruits; that is, the values decreased as the fruits matured, as described by Rodriguez (1987) and Davies and Albrigo (1994). The new cultivars, in comparison with 'Bahia Cabula' CV 25, presented lower acidity values at 7 and 8 months after anthesis (April and May), confirming the ripening and thus the early maturation of these cultivars.

According to Sartori et al. (1998) and Kallsen and Sanden (2011), with increased final size of the fruit, there is a reduction in the concentration of acids due to dilution. This decrease in the concentration of titratable acidity, concomitant with the increase in soluble solid content throughout fruit development, results in increased soluble solids/ titratable acidity ratio (SS/TA), used as a parameter to indicate the commercial maturation point. During the maturation process, the concentration of organic acids tends to decline in most citrus fruits as a result of the use of these compounds as a respiratory substrate and as carbon skeletons for the synthesis of new compounds (KAYS, 1991). 
Figure 5. Total soluble solid content (A) and acidity (B) of fruit juice of the orange cultivars 'Washington Navel' (CV 27), 'Washington Navel I' (CN 34), 'Robertson Navel' (CN 39), 'Bahia Valente' (CN 28), 'Golden Nugget Navel' (CN 41) and 'Bahia Cabula' (CV 25) 6 to 9 months after anthesis (Holambra, SP, 2013-2014.
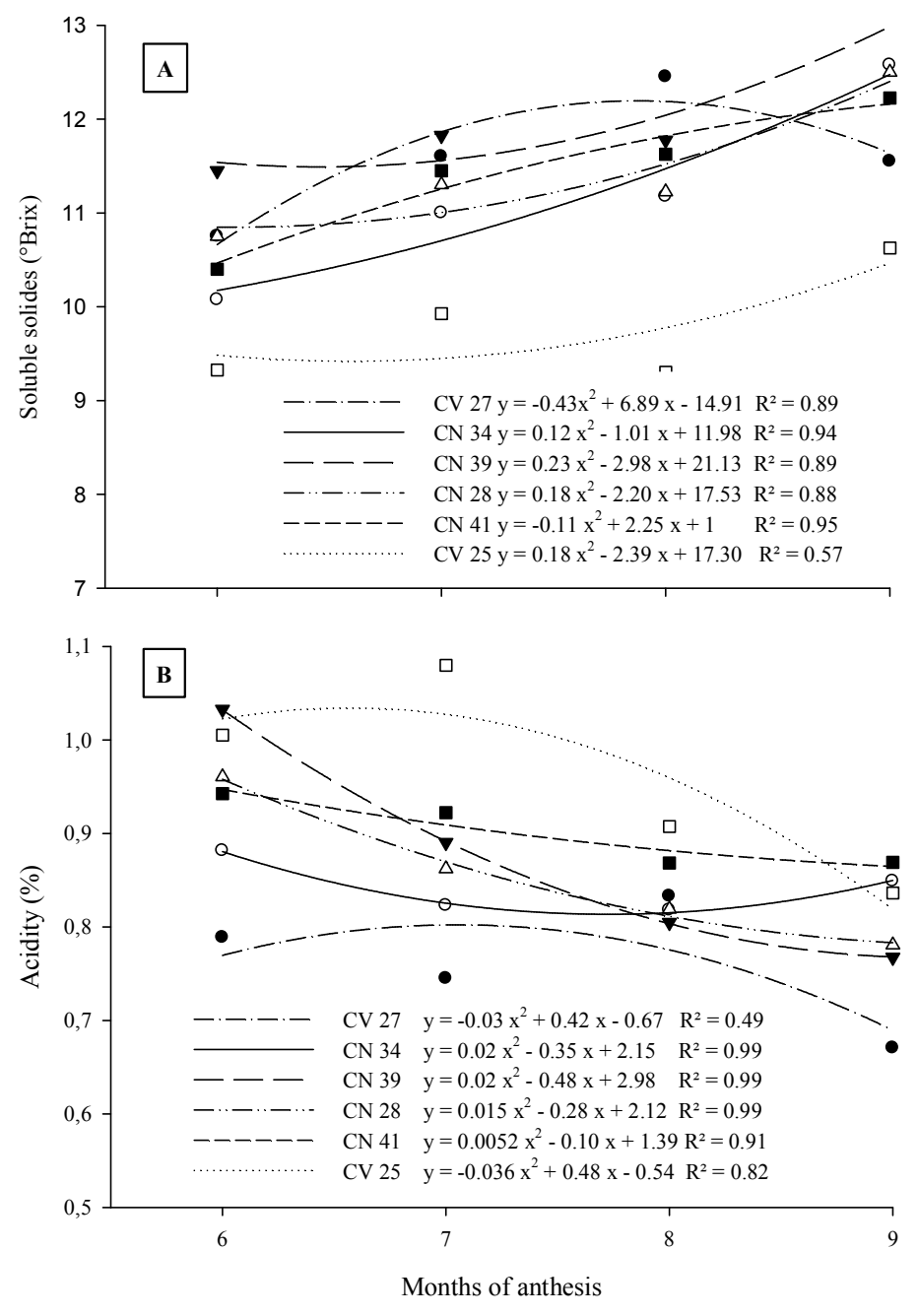

\section{Ratio of the juice}

All cultivars studied in this work, compared with the 'Bahia Cabula' orange (CV 25), currently marketed in São Paulo, showed earlier maturation. Beginning in March (6 months after anthesis), they had a minimum ratio of 10 , which is considered suitable for harvest according to the CEAGESP criteria (2000) (Figure 6). This characteristic is of utmost importance for the fresh fruit market because the relationship between soluble solid content and titratable acidity, also known as the ratio, correlates with fruit flavor. The values found in this work are in agreement with those of Couto and CanniattiBrazaca (2010) and Jones and Cree (1965), who consider ratios between 9 and 15 as ideal for fresh consumption. 
Figure 6. Mean ratio of fruit juice of the orange cultivars 'Washington Navel' (CV 27), 'Washington Navel I' (CN 34), 'Robertson Navel' (CN 39), 'Bahia Valente' (CN 28), 'Golden Nugget Navel' (CN 41) and 'Bahia Cabula' (CV 25) 6 to 9 months after anthesis (Holambra, SP, 2013-2014).

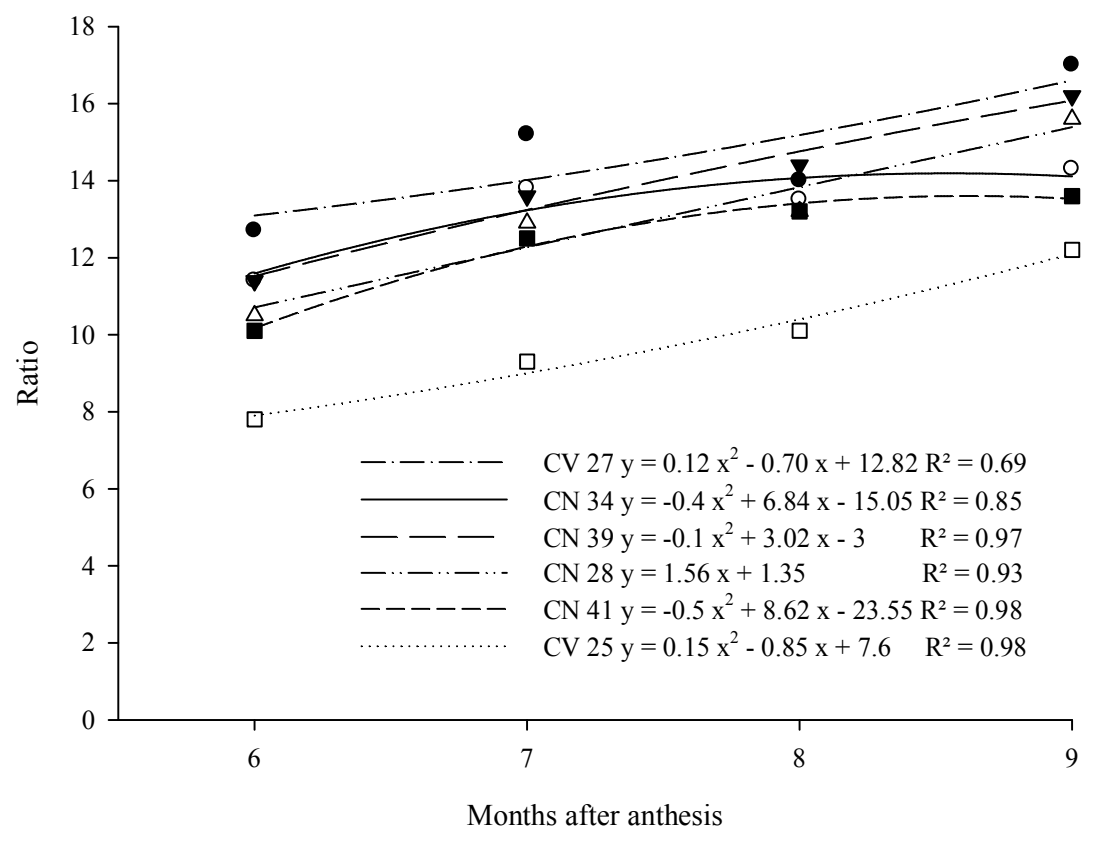

It can be inferred that the harvest of the new cultivars, in the agricultural and climate conditions of the study site (Holambra, SP), could be started in March. Thus, the cultivars studied can be classified as early maturing within the group of navel oranges. According to Gutierrez (2006), the highest supply of navel orange in CEAGESP occurs from April 15 to September 20, with $73 \%$ of the total volume. Producing and harvesting navel oranges before this period can be a profitable alternative for the producer.

In general, the production of later or earlier fruits is essential for the fresh fruit market because it can increase the supply of fruit throughout the year, allowing citrus growers to achieve greater profitability with good-quality fruits in the offseason period.

\section{Conclusion}

One can conclude that the physicochemical variables evaluated indicate the potential of the cultivars studied ('Bahia Valente', Golden Nugget, 'Robertson Navel', 'Washington Navel' and 'Washington Navel I') for fresh fruit marketing in the off-season period. This group of cultivars presented early maturation, while the 'Bahia Cabula' (CV 25) cultivar can be considered mid-season; thus, they are viable options for extending the harvest period of this orange group.

\section{Acknowledgments}

We thank the São Paulo Research Foundation - FAPESP (Process: 2011/18605-0) and the National Council of Technological and Scientific Development (CNPq) for financial support.

\section{References}

ALBRIGO, G. Influências ambientais no desenvolvimento dos frutos cítricos. In: SEMINÁRIO INTERNACIONAL DE CITROS - FISIOLOGIA, 2., Campinas, 1992. Anais... Campinas: Fundação Cargill, 1992. p. 100-106. 
BARBASSO, D. V.; PEDRO JÚNIOR, M. J. P.; PIO, R. M. Caracterização fenológica de variedades do tipo Murcott em três diferentes porta-enxertos. Revista Brasileira de Fruticultura, Jaboticabal, v. 27, n. 3, p. 399-403, 2005.

BASTIANEL, M.; SIMONETTI, L. M.; SCHINOR, E. H.; GIORGI, R. O.; NEGRI, J. D. de; GOMES, D. N.; AZEVEDO, F. A. Avaliação do banco de germoplasma de mexericas com relação às características físico-químicas e suscetibilidade à mancha marrom de alternária. Bragantia, Campinas, v. 73, n. 1, p. 23-31, 2014.

BRUGNARA, E. C.; SCHWARZ, S. F.; KOLLER, O. C.; BENDER, R. J.; WEILER, R. L.; GONZATTO, M. P.; SCHÄFER, G.; MARTINS, F. T.; LIMA, J. G. Portaenxertos para a tangerineira Michal no Rio Grande do Sul. Ciência Rural, Santa Maria, v. 39, n. 5, p. 13741379, 2009.

CAPUTO, M. M.; MOURÃO FILHO, F. A. A.; SILVA, S. R.; BREMER NETO, H. B.; COUTO, H. T. Z.; STUCHI, E. S. Seleção de variedades de laranja doce de maturação precoce por índices de desempenho. Pesquisa Agropecuária Brasileira, Brasília, v. 47, n. 11, p. 16691672, 2012.

COMPANHIA DE ENTREPOSTOS E ARMAZÉNS GERAIS DE SÃO PAULO - CEAGESP. Programa brasileiro para a melhoria dos padrões comerciais e embalagens de hortigranjeiros. Classificação da laranja (Citrus sinensis, Osbeck). São Paulo: CEAGESP, 2000. $8 \mathrm{p}$.

CHITARRA, M. I. F.; CHITARRA, A. B. Pós colheita de frutos e hortaliças: fisiologia e manuseio. Lavras: ESAL/ FAEPE, 1990. $320 \mathrm{p}$.

COUTO, M. A. L.; CANNIATTI-BRAZACA, S. G. Quantificação de vitamina $C$ e capacidade antioxidante de variedades cítricas. Ciência e Tecnologia de Alimentos, Campinas, v. 30, n. 1, p. 15-19, 2010.

DAVIES, F. S; ALBRIGO, L. G. Citrus. Wellingford: CAB International, 1994. 254 p.

GAYET, J. P.; SALVO FILHO, A. Colheita $e$ beneficiamento. Lima ácida Tahiti. Campinas: Instituto Agronômico, 2003. 162 p.

GRIZOTTO, R. K.; SILVA, J. A. A.; MIGUEL, F. B.; MODESTO, R. T.; VIEIRA JÚNIOR, J. B. Qualidade de frutos de laranjeira Valência cultivada sob sistema tecnificado. Revista Brasileira de Engenharia Agrícola e Ambiental, Campina Grande, v. 16, n. 7, p. 784-789, 2012.

GUTIERREZ, A. D. Estudos da comercialização de laranja na Ceasa de São Paulo com ênfase na variedade Baía. São Paulo: Ceasa, 2006. 43 p.
ISIDORO, M. M.; SILVA, M. F. G. F.; FERNANDES, J. B.; VIEIRA, P. C.; ARRUDA, A. C.; SILVA, S. C. Fitoquímica e quimiossistemática de Euxylophora paraensis (Rutaceae). Química Nova, São Paulo, v. 35, n. 11, p. 2119-2124, 2012.

JIMENEZ-CUESTA, M.; CUQUERELLA CAYUELA, J.; MARTINEZ-JAVEGA, J. M. Teoria y practicca de la desverdización de los cítricos. Madrid: INIA, 1983. $22 \mathrm{p}$.

JOMORI, M. L. L.; SASAKI, F. F. C.; BERNO, N. D.; GIMENES, L. C.; KLUGE, R. A. Desverdecimento e armazenamento refrigerado de tangor Murcott em função de concentração e tempo de exposição ao etileno. Semina: Ciências Agrárias, Londrina, v. 35, n. 2, p. 825834, 2014.

JONES, W.; CREE, C. B. Enviromental factors related to fruiting of Washington Navel oranges over a 38-year period. Proceedings of the American Society Horticultural Science, Alexandria, v. 86, n. 1, p. 267-271, 1965.

KALLSEN, C. E.; SANDEN, B. Early Navel orange fruit yield, quality, and maturity in response to lateseason water stress. HortScience, Alexandria, v. 46, n. 8 , p. 1163-1169, 2011.

KAYS, S. J. Postharvest physiology of perishable plant products. New York: Von Nostrand Reinhold, 1991. 532 p.

MACHADO, E. C.; MEDINA, C. L.; GOMES, M. M. A.; HABERMANN, G. Variação sazonal da fotossíntese, condutância estomática e potencial da água na folha de laranjeira Valência. Scientia Agricola, Piracicaba, v. 59, n. 1, p. 53-58, 2002.

NASCIMENTO, L. M.; SANTOS, P. C. Controle de doenças fúngicas e de danos por frio em pós-colheita de lima ácida Tahiti. Arquivos do Instituto Biológico, São Paulo, v. 80, n. 2, p. 193-205, 2013.

OLIVEIRA, R. P.; GONÇALVES, A. S.; SCIVITTARO, W. B.; NAKASU, B. Y. Fisiologia da formação de sementes em citros. Pelotas: Embrapa Clima Temperado, 2004. 27 p. (Embrapa Clima Temperado. Documentos, 119).

PACHECO, C. A.; MARTELLI, I. B.; POLYDORO, D. A.; SCHINOR, E. H.; PIO, R. M.; AZEVEDO, F. A. Resistance and susceptibility of mandarins and hybrids to Alternaria alternata. Scientia Agrícola, Piracicaba, v. 69, n. 6, p. 386-392, 2012.

PACHECO, C. A.; SCHINOR, E. H.; AZEVEDO, F. A.; BASTIANEL, M.; CRISTOFANI-YALY, M. Caracterização de frutos do tangor TMxLP 290 para mercado de fruta fresca. Revista Brasileira de Fruticultura, Jaboticabal, v. 36, n. 4, p. 805-812, 2014. 
PASSOS, O. S. A citricultura no Estado da Bahia de 1960 ao ano 2000. Cruz das Almas: EMBRAPA, 1998. $43 \mathrm{p}$.

PEREIRA, M E. C.; CANTILLANO, F. F.; GUTIEREZ, A. S. D.; ALMEIDA, G. V. B. Procedimentos póscolheita na produção integrada de citros. Cruz das Almas: Embrapa Mandioca e Fruticultura Tropical, 2006. $40 \mathrm{p}$.

PIMENTEL, R. M.; PIMENTEL, L. P. Tendência do mercado para frutas de uso imediato. [S.1.: s,n.] 2002. Disponível em: <http://www.ceinfo.cnpat.embrapa.br/ artigo.php?op $=1 \& \mathrm{i}=34 \& \mathrm{si}=48 \& \mathrm{ar}=658>$. Acesso em: 20 maio 2015.

PIO, M. R.; FIGUEIREDO, J. A.; STUCHI, E. S. Variedades Copa. In: MATTOS JUNIOR, D.; NEGRI, J. D. de; PIO, R. M.; POMPEU JUNIOR, J. (Ed.). Citros. Campinas: Instituto Agronômico e Fundag, 2005. Cap. 3, p. 39-60.
RODRIGUEZ, O. Ecofisiologia dos citros. In: CASTRO, P. R. C.; FERREIRA, S. O.; YAMADA, T. Ecofisiologia da produção agrícola. Piracicaba: Associação Brasileira para Pesquisa do Potassaio e do Fosfato, 1987. p. 149164.

ROSSI, F. R.; TORKOMIAN, A. L. V. O processo inovativo das indústrias processadoras de suco de laranja brasileiras e norte-americanas: uma comparação utilizando a análise de patentes. GEPROS. Gestão da Produção, Operações e Sistemas, Bauru, Ano 10, n. 3, p. 69-82, jul./set. 2015.

SARTORI, I. A.; SCHÄFER, G.; SCHWARZ, S. F.; KOLLER, O. C. Épocas de maturação de tangerinas na depressão central do Rio Grande do Sul. Revista Brasileira de Fruticultura, Jaboticabal, v. 20, n. 3, p. 313-322, 1998.

ZIEGLER, L. W.; WOLFE, H. S. Citrus growth in Florida. Gainesvifle: Press of Florida, 1975. 246 p. 
